\title{
Factors that Foster Teacher Educators' Engagement in Technology Learning in the Workplace
}

\author{
https://doi.org/10.3991/ijac.v12i2.10271 \\ Maurice Schols $(\square)$ \\ Fontys University of Applied Sciences, Tilburg, Netherlands \\ m.schols@fontys.nl
}

\begin{abstract}
New technologies are transforming every aspect of today's education, and teacher educators, teacher education institutions and policy makers are universally underscoring the need for adequate technology professionalisation programs. However, traditional professional development opportunities still leave much to be desired because educators perceive most of workshops, training and off-campus days as being separate from engagement with authentic teaching contexts. We conducted this study to explore and identify factors that foster teacher educators engagement in technology learning. Fifteen teacher educators from three interdisciplinary teams at a Dutch teacher education institution volunteered to participate in this qualitative study. We gathered data through reflective reports, semi-structured interviews and field observations. We found four factors that fostered teacher educators' engagement in technology learning and that are in line with the international engagement literature. The implications of the findings might contribute to teacher educators' technology professional development on both an individual level and institutional level.
\end{abstract}

Keywords - teacher educators, professionalisation, technology learning engagement

\section{$1 \quad$ Introduction}

Higher education (HE) has changed radically due to the advent of a global knowledge society in which the use of emerging technologies has increased over the past two decades. Factors such as changes in student profiles and different working and learning opportunities have led to a rethinking of traditional pedagogical approaches. Researchers and policymakers [1, 2, 3, 4] emphasise the importance of basic information and communication technologies (ICT) knowledge and skills for both teachers and students in a 21st-century learning context. Schools need teachers who are able to examine the versatile forms of knowledge and skills that are required to effectively integrate emerging technologies in their teaching practice. Fortunately, educators and teacher education institutions have become more aware of the importance of coming to grips with emerging technologies for educational purposes. As a result, the need for continuing professional development programs is 'gaining in- 
creasing attention at the level of both the national government and management boards of education institutions' [5, p.8].

Of importance is that realising meaningful continuing technology professional development (CTPD) entails developing ICT knowledge and skills for teacher educators that accommodates the learning needs of students who are tomorrow's teachers. Emerging technologies should support educational objectives that are in line with 21 st-century learning competencies $[6,7]$. However, despite the increasing pressures on the pursuit of more effective CTPD opportunities, most programs are ineffective and have been widely debated in recent decades (e.g. [5, 8, 9]).

Learning that is connected to teacher educators' practice is an important way of constructing knowledge and acquiring new technology skills, which is in line with several studies $[10,11,12]$ stating that learners best construct meaning from their work practice experiences. Fostering engagement in technology learning is therefore not only limited to traditional learning activities such as attending workshops or inclass courses $[5,13,14]$, but it also involves learning that is self-initiated. Professionals such as teacher educators learn from a range of formal, informal, individual and collective activities [5] through interactions with their peers [8, 15] as well as through experiences with their own students.

Despite the fact that teacher educators' technology professionalisation programs being one of the priorities of HE institutions [16, 17], not many studies focus on factors that foster teacher educators' engagement in technology learning. There is a need to understand what factors contribute to teacher educators' engagement in professional technology learning in the workplace in order to support teacher educators as they acquire new technology knowledge and skills. The following section considers enablers of engagement that researchers have identified and discussed in the international engagement literature.

\section{Literature Review}

To comprehend the complexity of the different lenses that are used in the international engagement literature, we use the conceptual organiser of engagement (see Table 1) designed by Zepke et al. [18].

Within the context of this study, we briefly discuss the literature on teacher engagement using the first four lenses and indicators that Zepke et al. [18] discussed. The rationale for choosing only the first four lenses in this research is that several research groups within the targeted Dutch teacher education institution have been studying teacher educators' professionalisation-related phenomena in the workplace that are congruent with the first four different perspectives of engagement by Zepke et al. [18] and the international engagement literature. In an attempt, to contribute to the discussion and gain a better understanding of educators' technology learning in the workplace, we further examine the relevance of the conceptual organiser within the context of this research in the following sections. 
Table 1. First four lenses of engagement based on conceptual organiser Zepke et al. [18, p.3]

\begin{tabular}{|c|c|}
\hline Lenses of engagement & Chosen indicators \\
\hline $\begin{array}{l}\text { Motivation and agency } \\
\text { (Engaged students are intrinsically moti- } \\
\text { vated and want to exercise their agency) }\end{array}$ & $\begin{array}{l}\text {-A student feels able to work autonomously } \\
\text {-A student feels they have relationships with } \\
\text { others } \\
\text {-A student feels competent to achieve success }\end{array}$ \\
\hline $\begin{array}{l}\text { Transactional engagement } \\
\text { (Students engage with teachers) }\end{array}$ & $\begin{array}{l}\text {-Students experience academic challenges } \\
\text {-Learning is active and collaborative inside and } \\
\text { outside the classroom } \\
\text {-Students and teachers interact constructively } \\
\text {-Students have enriching educational experiences }\end{array}$ \\
\hline $\begin{array}{l}\text { Transactional engagement } \\
\text { (Students engage with each other) }\end{array}$ & $\begin{array}{l}\text {-Learning is active and collaborative inside and } \\
\text { outside the classroom } \\
\text {-Students have positive, constructive peer } \\
\text { relationships } \\
\text {-Students use social skills to engage with others }\end{array}$ \\
\hline $\begin{array}{l}\text { Institutional support } \\
\text { (Institutions provide an environment con- } \\
\text { ducive to learning) }\end{array}$ & $\begin{array}{l}\text {-There is a strong focus on student success } \\
\text {-There are high expectations of students } \\
\text {-There is an investment in a variety of support } \\
\text { services } \\
\text {-Diversity is valued } \\
\text {-Institutions continuously improve }\end{array}$ \\
\hline
\end{tabular}

\subsection{Teacher motivation and agency}

In the past, many studies on engagement treated motivation as a unitary concept. This approach changed in the 1980s when Deci and Ryan [19] published the selfdetermination theory (SDT), in which they distinguished 'different types of motivation based on the different goals that rise to an action' (p. 55). The SDT considers a difference between intrinsic motivation referring 'to doing something because it is inherently interesting or enjoyable', and extrinsic motivation which refers 'to doing something because it leads to a separable outcome' $[19$, p. 55]. In their SDT, Deci and Ryan [19] introduce a sub-theory referred to as organismic integration theory; it breaks down intrinsic motivation into four sub-types: external regulation, introjection, identification, and integration. However, to discuss all four sub-types in detail would go beyond the scope of this research. Based on the SDT, intrinsic motivation is most likely to support a learners' self-determination (the degree to which an individual is self-motivated) because it focuses on activities that are done 'for its inherent satisfaction rather than for some separable consequence' $[19$, p. 56]. The conceptual organiser that Zepke et al. [18] discuss considers intrinsic motivation as an important form of motivation to engage in learning; several other studies have supported this (e.g. [20, $21,22])$. Additionally, other studies underscore the fact that learners are more intrinsically motivated when they become agents of their own learning process. As Little [23] makes clear, 'autonomous learners are motivated and reflective learners' (p. 273).

In the context of this research, exploring teacher educators' intrinsic motivation with regard to engagement in technology learning might contribute to a better understanding of teacher educators' personal professional learning needs and wishes in the workplace. 


\subsection{Transactional engagement (teacher-student interaction)}

The second lens that influences engagement in learning by Zepke et al. [18] and Zepke and Leach [24], focuses on student-teacher interactions. Several studies (e.g. $[25,26,27,28])$ emphasise that teachers and their teaching practice are crucial to students' learning engagement. For example, Bryson and Hand [25] concluded in their research that students are more engaged in learning when their teachers provide them with challenging and inviting learning opportunities and environments. In line with Bryson and Hand's [25] research, Schlusser [28] discusses how student engagement is fostered when students perceive that they 'are respected as learners' (p. 114). This respect occurs when teachers provide learners with learning activities that are 'at appropriate levels' and when teachers provide adequate 'academic support' (p.114). Traditional models of pedagogy in which the teacher is considered to be the broadcaster or transmitter of knowledge, has become obsolete. Now, the emphasis is more on meaningful academic challenges for students that foster cognitive development and that can be a driver for engagement. Teachers should spend more time in discussion with students, which fosters mutual exploration of issues, problems and contributes to knowledge construction.

\subsection{Transactional engagement (teacher-teacher interaction)}

The third lens used to investigate influences on engagement focuses on teacherteacher interactions. International studies on engagement have shown that peer-topeer interaction is quintessential to fostering engagement in learning [27, 29, 30]. Several researchers (e.g. [31, 32, 33]) have provided 'evidence for peers as socializing agents of engagement' in learning [33, p.104]. In the present study, we use Boud's [34] definition, who considers peer learning as a process 'which involves participants learning from and with each other in both formal and informal ways' (p. 6) and emphasises that peer learning 'includes mutual benefits and a sharing of knowledge, ideas and experience among participants' (p. 4).

Learning from peers is grounded in educational theory, such as the constructivist theory of education. In general, constructivists view knowledge as a process that is structured by the learners' personal experiences. New experiences from the environment are added to prior understandings and knowledge [35] that are used to create a new cognitive structure. Learners reconstruct a reality through newly acquired experiences in which 'knowledge is an autonomous and subjective construction' [35, p. 8]. Professional learning communities, such as communities of practice $[8,15,31,36]$, facilitate opportunities that contribute to 'knowledge sharing and learning' [37, p. 1].

However, engaging learners in a group of peers is not an easy task. Getting teacher educators started on a course or collaborating with the intention to improve their professional skills 'takes a committed and skilled leader or facilitator' [38, p. 41]. Moreover, if they are to engage in joint activities, teacher educators 'need compelling reasons to begin collaborating' $[38$, p. 41$)$. 


\subsection{Institutional support}

In the conceptual organiser of engagement [18], the fourth lens focuses on the institutional support. Several studies on technology adoption in educational contexts show that users' perceptions of institutional support are one of the main factors influencing whether an educator is willing to learn and make use of emerging technologies in the classroom [39, 40, 41]. In these studies, lack of time is reported as one of the biggest constraints to the uptake of new technologies. The problem of time limitations affecting the integration of new technologies in education is caused by busy schedules and heavy workloads $[39,42,43]$. Consequently, teachers do not have sufficient time to design, develop and experiment with emerging technologies and new pedagogical methods $[43,44]$. Teachers need sufficient time to familiarise themselves with new technologies, and they need time to acquire the pedagogical knowledge to adequately integrate technologies into their teaching practice. Providing teachers with sufficient time is therefore a prerequisite for experimenting with technology-enriched methods that contribute to educators' technology development [5].

Teachers' professionalisation is a key factor in successfully integrating new technologies into the classroom. However, the barrier that research about the uptake of ICT in education most frequently referred to is the lack of adequate professionalisation opportunities [39, 45, 46]. Studies (e.g. [5, 47]) have revealed that if teachers are provided with professional development programs that are connected to their teaching practice that involves adequate support, teachers are more willing to adopt and integrate ICT into their teaching. Developmental opportunities should therefore not only be limited to formal on-campus training opportunities, but they should also comprise informal learning possibilities.

\section{Objective of the Study}

The main objective underpinning the present study is determining what factors foster teacher educators' engagement in technology learning using the conceptual organiser by Zepke et al. [18]. Examining teacher educators' perceived engagement in technology learning might provide guidance for ways to develop adequate professionalisation trajectories that are key to the uptake of emerging technologies and pedagogies in teaching. Consequently, we addressed two research questions:

- What factors facilitate teacher educators' engagement in technology learning based on the lenses of the conceptual organiser of engagement [18]?

- What are the implications concerning teacher educators' use of technology with professionalisation opportunities?

\section{$4 \quad$ Research Method}

This study is part of a larger project on teacher educators' technology professionalisation strategies within a Dutch teacher education institution. As the quality of teach- 
er education depends to a large extent on the quality of teacher educators' continuing professionalisation processes, fostering engagement in learning is key to managing and sustaining teacher educators' professionalisation. Our intention was to collect mainly qualitative data; this is in line with Miles and Huberman [48], who state that qualitative approaches are suitable for exploring beliefs and ideas that allow for a more profound understanding of the research phenomenon.

\subsection{Participants}

The research participants in this study were teacher educators from a Dutch teacher education institution (see Table 2). We sent invitations to 51 educators from three interdisciplinary teams via e-mail. From all three teams 15 teacher educators were willing to participate. Prior to the data collection, the 15 participants who volunteered, received an invitation to join a short session (lasting 45 minutes) in which we made the purpose of the research clear.

Table 2. Overview of the composition of the interdisciplinary teams $(n=15)$

\begin{tabular}{|l|c|c|c|}
\hline \multicolumn{1}{|c|}{ Teacher educators } & $\begin{array}{c}\text { Team Alfa } \\
(\mathbf{n}=\mathbf{5}) \\
(\mathbf{3} \text { f. and 2 } \mathbf{~ m .})\end{array}$ & $\begin{array}{c}\text { Team Beta(n= 5) } \\
(\mathbf{2} \text { f. and 3 m. })\end{array}$ & $\begin{array}{c}\text { Team Gamma(n= 5) } \\
\text { (3 f. and 2 m. })\end{array}$ \\
\hline Subject area & Dutch, French, English & $\begin{array}{c}\text { Economics, math, chem- } \\
\text { istry }\end{array}$ & $\begin{array}{c}\text { Geography, } \\
\text { history }\end{array}$ \\
\hline Age & $46.0(7.9)$ & $48.8(5.6)$ & $42.4(4.4)$ \\
\hline Teaching experience & $16.6(6.7)$ & $17.4(4.0)$ & $13.2(3.7)$ \\
\hline
\end{tabular}

Data are presented as f. (females), m. (males); age and teaching experience in years is represented as mean, and standard deviation in brackets.

\subsection{Collection instruments}

We collected data over the course of one semester during the academic year 2018 and included

- Semi-structured group interviews

- Participants' reflective reports

- Field notes

We conducted three semi-structured group interviews that we recorded using a digital dictaphone application; we then transcribed the interviews verbatim. We organised the semi-structured interview guide around a set of predetermined questions that were related to the different lenses of engagement that Zepke et al. [18] discussed in their conceptual organiser. We compared all the interview sequences from the three group interviews with the participants' individual responses from the reflective reports.

Before conducting the semi-structured group interviews, we asked the research participants to write down their own 'moments of engagement in technology learning'. 
The questions we used for the reflective reports were identical to the interview guide we used during the group interviews. In this way, the reflective reports 'provided access to phenomenological data such as the respondents' perceptions of themselves and their world' [5, p. 62] and minimised the influence of other colleagues' experiences, ideas and views about technology professional learning.

During the research process, we took field notes consisting of two parts. First, we took field notes that were based on recorded events that occurred in situ; this ensured that details were not lost to our memory. Second, we wrote memos that were based on long-term observations that enabled us to capture more broader patterns that could be relevant to the analysis process.

\subsection{Data analysis procedure}

We used a grounded theory approach to analyse the qualitative data. Using the conceptual organiser [18] 'as a possible source of inspiration, ideas, "Aha!" experiences, creative associations, critical reflections and multiple lenses' [49, p. 91] is in accordance with a constructivist grounded theory approach [50] in which established theories and research findings are treated as provisional [49].

The analysis process consisted of three phases: open coding, focused coding and theoretical coding [50]. During the open coding phase, we closely analysed the reflective reports and transcripts of the semi-structured group interviews and created preliminary codes and categories grounded in the data. Based on Glaser [51] and Charmaz' [50] suggestions to stay close to the data, we used specific questions: 'What category does this incident indicate? What is actually happening in the data?' [52, $\mathrm{p}$. 57]; 'What process is at issue here? What might his or her observed behaviour indicate?' [53, p. 51].

During the second phase, the focused coding process, we further developed initial codes and categories based on an iterative approach in which we separated, sorted and synthesized the data to create more specific categories or themes $[49,50]$.

The final phase, known as the theoretical coding process [50, 51, 52, 53], focused on the identification of specific patterns that related to the core categories already discussed in this paper. Using Atlas.ti. 7.5.6 allowed us to analyse primary data sets in a systematic way, which enhanced the qualitative analysis process.

To check the reliability of the core categories, we invited a second coder to independently analyse the transcripts of the semi-structured interviews and reflective reports. In order to allow the second coder to familiarise herself with the research purpose and the construct of the coding process, both coders analysed three transcripts together in a session and discussed the codes and categories. The data analysis revealed four main factors that were in line with the literature review and conceptual organiser from Zepke et al. [18]. We discuss these categories in the following section (see Figure 1 for an overview of the coding process). The per cent agreement for factor 1 was $88 \%$, for factor 2 was $82 \%$, for factor 3 was $91 \%$, and for factor 4 was $92 \%$. Based on Miles and Huberman [48], the percentage of agreement for each categorisation indicates sufficient inter-coder consistency [48]. 


\begin{tabular}{|c|c|c|}
\hline Examples initial coding & Clustered coding & Main factors \\
\hline $\begin{array}{l}\text { Working together with colleagues } \\
\text { improves practice }\end{array}$ & Collaboration - & $\begin{array}{l}\text { 1. Collective } \\
\text { efficacy }\end{array}$ \\
\hline $\begin{array}{l}\text { In charge of personal leaming } \\
\text { process motivates }\end{array}$ & have greater impact & $\begin{array}{l}\text { 2. Autonomous } \\
\text { leaming }\end{array}$ \\
\hline $\begin{array}{l}\text { Appreciation when students help } \\
\text { with new technologies }\end{array}$ & $\begin{array}{l}\text { Personal leaming } \\
\text { needs and wishes }\end{array}$ & $\begin{array}{l}\text { Collaborating } \\
\text { with students }\end{array}$ \\
\hline $\begin{array}{l}\text { Management should have a clear } \\
\text { vision about the use of technolo- } \\
\text { gies }\end{array}$ & $\begin{array}{l}\text { Joint working with } \\
\text { students } \\
\text { Clear strategy }\end{array}$ & $\begin{array}{l}\text { Institutional driv- } \\
\text { ers }\end{array}$ \\
\hline
\end{tabular}

Fig. 1. Overview of the coding process (sample statements and sample clustered codes)

\section{$5 \quad$ Results}

As shown in Figure 1, the data analysis revealed four main factors that contributed to educators' engagement in technology learning in the workplace: 1) collective efficacy, which refers to the interaction of teacher educators; factor 2) autonomous learning, which applies to self-directed learning; factor 3) collaborating with students, which focuses on collaborating and learning from and with students; and factor 4) sufficient institutional support, which applies to institutional drivers that foster teacher educators technology learning. Each factor will be explored respectively. Table 3 shows how often we found these four different factors in the reflective reports and semi-structured group interviews.

Table 3. Distribution of frequencies of factors that foster engagement in technology learning

\begin{tabular}{|l|c|c|c|c|}
\hline & Team Alfa & Team Beta & Team Gamma & \\
\hline Resp. & $\boldsymbol{a} \boldsymbol{b} \boldsymbol{c} \boldsymbol{d} \boldsymbol{e}$ & $\boldsymbol{a} \boldsymbol{b} \boldsymbol{c} \boldsymbol{d} \boldsymbol{e}$ & $\boldsymbol{a} \boldsymbol{b} \boldsymbol{c} \boldsymbol{d} \boldsymbol{e}$ & Total \\
\hline F1 & 32223 & 22323 & 23323 & 37 \\
\hline F2 & 22333 & 32324 & 24333 & 42 \\
\hline F3 & 33222 & 23423 & 32323 & 39 \\
\hline F4 & 01102 & 20122 & 23120 & 19 \\
\hline
\end{tabular}

Data are presented as Resp. (Respondents), Fx (Factors 1, 2, 3, 4)

Table 3 illustrates that factor 2 occurred most frequently, and that factors 1 and 3 were valued almost equally. However, four participants considered factor 4 to be an unimportant driver in fostering teacher educators' engagement in technology learning. Based on the responses from the semi-structured interviews and statements in the reflective reports, teacher educators valued collaborating with colleagues in an interdisciplinary setting, which contributed to new knowledge and skills. The following quote illustrates this experience: 
During our study days, I appreciated the moments when my colleagues gave feedback on the use of new technologies in my teaching practice. Especially feedback from colleagues who belong to a different department helped me to rethink why I use what technology and when. (Educator semilKM)

Moreover, the exploration of factors 1 and 3 shows that educators valued not only collaborating with peers, but they also valued working and learning together with students. The educators indicated two important aspects. First, collaborating with students motivated teacher educators to use new technologies in their teaching, as it gave them new insights about teaching and learning from the perspective of students. Two, they noticed that students became more actively involved in the learning process, which encouraged them to challenge students more. This is evident in the following example:

As I worked together with three students who helped me to learn how to use a new application, I noticed that I never had thought about it in the way my students had used it, for example, social media in their learning process. I was glad to see that my students liked the fact that they could help me, and this suggested new possibilities for teaching and learning. (Educator semilCH)

The teacher educators considered factor 2, autonomous learning, to be the most important factor fostering educators' engagement in technology learning. They stated that whenever they were more in charge of their own learning process with regard to the acquisition of new technology knowledge and skills, their learning was more meaningful and context-related, adding to their motivation:

What I find important is that I can decide when to learn and what to learn. I find it important that learning about the potential benefits of new technologies suits my teaching needs and wishes. When learning is more focussed on my needs, I am more willing to use ICT in my classroom. (Educator semilMZ)

Teacher educators must be able to provide for their own learning needs and wishes, if they are to acquire the new technology knowledge and skills they want.

The research participants valued factor 4, which applies to institutional support, less. The teacher educators stated that a clear mission with regard to using emerging technologies within the teacher education institution was a prerequisite for the uptake of ICT. However, several educators felt that sufficient time to experiment with peers and students was essential for engaging in technology learning, as was made clear in the following statement from one of the participants: '...enough time to trial new teaching practices and collaborate with colleagues and students is very crucial to examine the benefits of technologies in my daily teaching practice' (EducatorREF23ZF).

\section{Discussion}

A limitation of the present study is that the small sample size limits our ability to generalise the findings concerning factors that foster teacher educators' engagement in technology learning. That generalisations are difficult to make is in line with Shaughnessy et al. [54], who state that generalising findings can be done when they 
can be extrapolated to other contexts with different characteristics, allowing them to make assertions with regard to outcomes about recurring practice. Another limitation of this study is that we only incorporated the first four lenses based on Zepke et al. [18]. However, despite these limitations, the findings have important implications on two levels for practice and researching factors that contribute to teacher educators' engagement in technology learning.

On an individual level, several factors foster teacher educators' engagement in technology learning, and our results are in line with the international engagement literature. However, analysis of the data in this research underscores the importance of collective learning. During the group interviews and in the reflective reports, teacher educators emphasised that not only learning from and with colleagues but also from and with students motivated them to use new technologies more often in their teaching practice. Moreover, several participants stated that collective learning contributed to a rethinking of traditional pedagogical approaches. For educators, this suggests that it is important to engage in critical reflection through critical dialogue with other colleagues and students. One suggestion for teacher educators could be creating learning communities that consist of students and colleagues.

On the institutional level, it is crucial that teacher education institutions need to have a clear vision or plan about the use and integration of emerging technologies in curricula and provide sufficient ICT support and resources. Additionally, it is quintessential that educators have ample time and opportunities to explore issues, together with colleagues and students, regarding the integration of ICT in teaching and learning. Experimenting with emerging technologies and new pedagogical methods allows them to reflect on teaching and learning, which increases not only self-awareness among educators but also engagement in the use of emerging technologies.

This research raises a number of issues and has opened up areas for study that can further shape our understanding of teacher educators' engagement in technology professional learning. Firstly, it would be interesting to investigate the effects of designing professional development trajectories based on the main factors that emerged during the study. Secondly, it would be desirable to investigate the factors more profoundly among a larger group of teacher educators. Finally, as far as generalisability is concerned, we only investigated factors that emerged within one specific teacher education institution. It is possible that investigating teacher educators' engagement in technology learning at other teacher education institutions might yield different results.

\section{$7 \quad$ References}

[1] Bellanca, J, \& Brandt, R. (2010). 21st learning skills: thinking how students learn. Bloomington: Solution Tree Press.

[2] Collins, A., \& Halverson, R. (2009). Rethinking education in the age of technology: The digital revolution and schooling in America. New York: Teachers College Press.

[3] Keane, T., Keane, W., \& Blicblau, A. (2014). Beyond traditional literacy: Learning and transformative practices using ICT. Education and Information Technologies, 21(4), 1-13. http://doi.org/10.1007/s10639-014-9353-5 
[4] Vahtivuori-Hänninen, S., Halinen, I., Niemi, H., Lavonen, J., Lipponen, L., \& Multisilta, J. (2014). A new Finnish national core curriculum for basic education (2014) and technology as an integrated tool for learning. In Niemi, H., Multisilta, J., Lipponen, L. \& Vivitsou, M. (Eds.), Finnish innovations and technologies in schools: A guide towards new ecosystems of learning. Rotterdam: Sense Publishers. https://doi.org/10.1007/978-94-6209-749-0 2

[5] Schols, M. (2015). Continuing technology professional development: A technology learning preferences instrument to support teacher educators' workplace learning (Doctoral dissertation). Roehampton University, London. Retrieved from Roehampton Research Explorer. https://pure.roehampton.ac.uk/portal/files/420518/Maurice_Schols Thesis.pdf

[6] Drent, M., \& Meelissen, M. (2008). Which factors obstruct or stimulate teacher educators to use ICT innovatively? Computers \& Education, 51(1), 187-199. https://doi.org/10.1016/ j.compedu.2007.05.001

[7] Voogt, J., \& Roblin, N. (2012). A comparative analysis of international frameworks for $21^{\text {st }}$ century competences: Implications for national curriculum policies. Journal of Curriculum Studies, 44(3). 299-321. http://dx.doi.org/10.1080/00220272.2012.668938.

[8] Darling-Hammond, L., \& Richardson, N. (2009). Teacher learning: What matters. Educational Leadership, 66(5), 46-53.

[9] Schrum, L. (1999). TPD for teachers. Educational Technology Research and Development, 47(4), 83-90.

[10] Ball, D., \& Forzani, F. (2011). Building a common core for learning to teach, and connecting professional learning to practice. American Educator, 35(2), 17-21.

[11] Billet, S., \& Somerville, M. (2004). Transformations at Work: Identity and Learning. Studies in Continuing Education, 26(2): 309-326. https://doi.org/10.1080/1580370420002252 $\underline{72}$

[12] Herrington, A., \& Herrington, J. (2006). What is an authentic learning environment? In A. Herrington \& J. Herrington (Eds.), Authentic learning environments in higher education Hershey, PA: Information Science Publishing. https://doi.org/10.4018/9781591405948.ch $\underline{001}$

[13] Hargreaves, A. (2003). Teaching in the Knowledge Society: Education in the age of insecurity. New York: Teachers College Press.

[14] Lieberman, A., \& Pointer Mace, D. (2010). Making practice public: Teacher learning in the 21st century. Journal of Teacher Education, 61(1-2), 77-88. https://doi.org/10.1177/00 22487109347319

[15] Voogt J., Westbroek, H., Handelzalts, A., Walraven, A., Mckenney, S., Pieters, J., \& De Vries, B. (2011). Teacher learning in collaborative curriculum design. Teaching and Teacher Education, 27(8), 1235-1244. https://doi.org/10.1016/j.tate.2011.07.003

[16] Cochran-Smith, M., \& Fries, K. (2005). The AERA Panel on Research and Teacher Education: Context and goals. In M. Cochran-Smith \& K. M. Zeichner (Eds.), Studying teacher education: The report of the AERA Panel on Research and Teacher Education. Mahwah, NJ: Erlbaum. https://doi.org/10.4324/9780203864043

[17] Ertmer, P., \& Ottenbreit-Leftwich, A. (2010). Teacher technology change: how knowledge, beliefs, and culture intersect. Journal of Research on Technology in Education, 42, 255-284. https://doi.org/10.1080/15391523.2010.10782551

[18] Zepke, N., Leach, L., \& Butler, P. (2010). Student engagement: What is it and what influences it? Wellington, Teaching and Learning Research Initiative. Retrieved from http:// www.tlri.org.nz/sites/default/files/projects/9261-Introduction.pdf

[19] Deci, E., \& Ryan, R. (1985). Intrinsic motivation and self-determination in human behavior. New York: Plenum Press. 
[20] Lee, W., \& Reeve, J. (2012). Teachers' estimates of their students' motivation and engagement: Being in synch with students. Educational Psychology, 32, 727-747. https://doi. org/10.1080/01443410.2012.732385

[21] Vansteenkiste, M., Sierens, E., Soenens, B., Luyckx, K., \& Lens, W. (2009). Motivational profiles from a self-determination perspective: The quality of motivation matters. Journal of Educational Psychology, 101(3), 671-688. https://doi.org/10.1037/a0015083

[22] Wlodkowski, R., \& Ginsberg, M. (2017). Enhancing adult motivation to learn: A comprehensive guide for teaching all adults. Jossey-Bass, San Francisco. https://doi.org/10.1177/ $\underline{0741713609350425}$

[23] Little, D., \& Dam, L. (1998). Learner autonomy: What and why? The Language Teacher, 22(10), 7-8.

[24] Zepke, N., \& Leach, L. (2010). Improving student engagement: Ten proposals for action. Active Learning in Higher Education, 11(3), 167-77. https://doi.org/10.1177/1469787410 $\underline{379680}$

[25] Bryson, C., \& Hand, L. (2007). The role of engagement in inspiring teaching and learning. Innovations in Education and Teaching International, 44(4), 349-62. https://doi.org/10.10 $\underline{80 / 14703290701602748}$

[26] Christenson, S., Reschly, A., \& Wylie, C. (2012). Handbook of research on student engagement. New York, NY: Springer.

[27] Kuh, G. D., Kinzie, J., Cruce, T., Shoup, R., and Gonyea, R. (2006). Connecting the dots: Multifaceted analyses of the relationships between student engagement results from the NSSE and the institutional policies and conditions that foster student success. Final report to Lumina Foundation for Education. Bloomington, IN: Indiana University, Center for Postsecondary Research. Retrieved from nsse.iub.edu/pdf/Connecting the Dots Report. pdf.

[28] Schussler, D. (2009). Beyond content: How teachers manage classrooms to facilitate intellectual engagement for disengaged students. Theory Into Practice, 48, 114-121. https:// doi.org/10.1080/00405840902776376

[29] Conrad, R., \& Donaldson, J. (2004). Engaging the online learner: Activities and resources for creative instruction. San Francisco: Jossey-Bass. https://doi.org/10.1111/teth.12217

[30] Juedes, J. (2010). Outcomes of peer education on student learning in higher education. Journal of Student Affairs, 20, 65-70.

[31] Wenger, E. (1998). Communities of practice. Cambridge: Cambridge University Press.

[32] Ryan, A., \& Patrick, H. (2001). The classroom social environment and changes in adolescents' motivation and engagement during middle school. American Educational Research Journal, 28, 437-460. https://doi.org/10.3102/00028312038002437

[33] Ryan, A. (2000). Peer groups as a context for the socialization of adolescents' motivation, engagement, and achievement in school. Educational Psychologist, 35, 101-111. https:// doi.org/10.1207/s15326985ep3502 4

[34] Boud, D. (1999). Situating academic development in professional work: using peer learning. International Journal for Academic Development, 4(1), pp. 3-10. https://doi.org/10.10 $\underline{80 / 1360144990040102}$

[35] Pelech J, \& Pieper G. (2010). The comprehensive handbook of constructivist teaching. Charlotte, NC: Information Age Pub.

[36] Stoll, L., \& Louis, K. (2007). Professional learning communities: divergence, depth and dilemmas. Berkshire, England: Open University Press.

[37] Coto, M., \& Dirckinck-Holmfeld, L. (2008). Facilitating communities of practice in teacher professional development. 6th International Conference on Networked learning. Halkidiki, Greece. 5-6 May 2008. 
[38] McLaughlin, M., \& Talbert, J. (2006). Building school-based teacher learning communities: Professional strategies to improve student achievement. New York: Teachers College Press.

[39] Bingimlas, K. (2009). Barriers to the successful integration of ICT in Teaching and learning environments: A review of the literature. Eurasia Journal of Mathematics, Science \& Technology, 5(3), 235-245. https://doi.org/10.12973/ejmste/75275

[40] Agyei, D., \& Voogt, J. (2011). Exploring the potential of the will, skill, tool model in Ghana: predicting prospective and practicing teachers' use of technology. Computers \& Education, 56(1), 91-100. https://doi.org/10.1016/j.compedu.2010.08.017

[41] Prestridge, S. (2012). The beliefs behind the teacher that influences their ICT practices. Computers \& Education, 58(1), 449-458. https://doi.org/10.1016/j.compedu.2011.08.028

[42] Neyland, E. (2011). Integrating online learning in NSW secondary schools: Three schools perspectives on ICT adoption. Australia Journal of Educational Technology, 27(1), 152173. https://doi.org/10.14742/ajet.989

[43] Khan, S., Hasan, M., \& Clement, C. (2012). Barriers to the introduction of ICT into education in developing countries: The example of Bangladesh. International Journal of Instruction, 5(2), 61-80.

[44] Afshari M., Bakar, K., Luan, W., Samah, B., \& Fooi, F. (2009). Factors affecting teachers' use of Information and Communication Technology. International Journal of Instruction, 2(1), 77-104.

[45] Goktas Y., Gedik, N., \& Baydas, O. (2013). Enablers and barriers to the use of ICT in primary schools in Turkey: A comparative study of 2005-2011. Computers \& Education, 68, 211-222. https://doi.org/10.1016/j.compedu.2013.05.002

[46] Albion, P., Tondeur, J., Forkosh-Baruch, A., \& Peeraer, J. (2015). Teachers' professional development for ICT integration: Towards a reciprocal relationship between research and practice. Education and Information Technologies, 20(4), 655-673. https://doi.org/10.10 07/s10639-015-9401-9

[47] Tondeur, J., Van Braak, J., Sang, G., Voogt, J., Fisser, P., \& Ottenbreit-Leftwich, A. (2012). Preparing pre-service teachers to integrate technology in education: A Synthesis of qualitative evidence. Computers \& Education, 59(1), 134-144. https://doi.org/10.1016/j. compedu.2011.10.009

[48] Miles, M., \& Huberman, M., (1994). Qualitative data analysis: An expanded sourcebook. London: Sage Publications.

[49] Thornberg, R. (2012). Grounded Theory. In Arthur, J., Waring, M., Coe, R., \& Hedges, L. (Eds.), Research methods \& methodologies in education. London: Sage.

[50] Charmaz, K., \& Bryant, A. (2012). The Sage handbook of Grounded Theory. London: Sage.

[51] Glaser, B. (1998). Doing Grounded Theory: Issues and discussions. Mill Valley, CA: Sociology Press.

[52] Glaser, B. (1978). Theoretical Sensitivity: Advances in the Methodology of Grounded Theory. Mill Valley, CA: Sociology Press.

[53] Charmaz, K. (2006). Constructing Grounded Theory. London: Sage Publishers.

[54] Shaughnessy J., Zechmeister E., \& Zechmeister J. (2000). Research methods in psychology. Boston, MA: McGraw-Hill Companies. 


\section{Author}

Maurice Schols holds a doctorate degree in education and works as a senior teacher educator and researcher at a teacher education institution in the Netherlands. His research interests include teacher educators' technology professionalization, ICT competency frameworks, lesson study and self-regulated learning in the workplace.

Article submitted 2019-02-05. Resubmitted 2019-04-08. Final acceptance 2019-04-09. Final version published as submitted by the authors. 